\section{TEACHING \& LEARNING}

Senge, P. (1996). Leading learning organizations: the bold, the powerful and the invisible in Hesselbein, M. Goldsmith, and R. Beckhard, eds. Leader of the future. San Francisco: Jossey-Bass Inc.

Senge, P.M. (1990). The fifth discipline. New York: Doubleday.

Shaw, P. (1999). Purpose and process in effective learning communities (pp. 149-170) in J. Retallick, B. Cocklin \& K. Coombe, eds. Learning communities in education: Issues, strategies and contexts. London \& New York, Routledge.

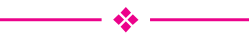

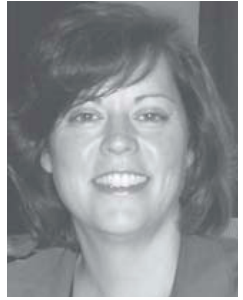

Dale R. Petruka, Ph.D. is a principal for the Brant Haldimand Norfolk Catholic District School Board. She is currently balancing principalship, motherhood, and research endeavours. She has been a part-time professor in the B.Ed. program at the University of Ottawa and co-taught Special Education Part I while earning her doctorate. Her research interests include educational leadership, special education, and collaboration.
4:2 Fall 2007

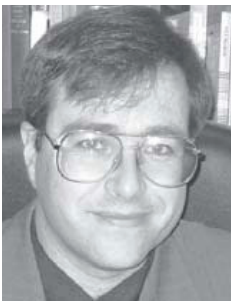

Kurt W. Clausen, $\mathrm{Ph} . \mathrm{D}$. is an assistant professor of Education and past chair of Graduate Studies at Nipissing University. He presently teaches preservice courses in curriculum development and is the editor of the on-line journal, The Ontario Action Researcher. His research interests include educational leadership, the history of the curriculum, alternative curriculum models and action research methods.

\title{
Roch Carrier: Short stories for FSL students
}

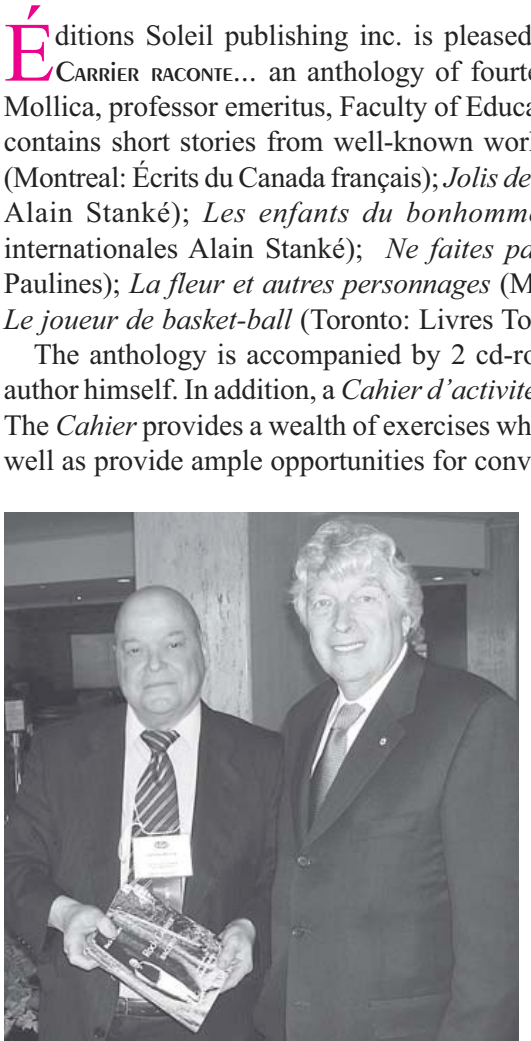

Anthony Mollica presents copies of Roch CARRIER RACONIE... to the author, Rock Carrier. that an author reads the short stories in an anthology destined for French as a second language (FSL). It's a publisher's first," said Mollica. To reach a wider audience, Mollica has provided marginal vocabulary to assist the students when reading the short stories as well as a French-English glossary. The anthology is suitable for both French as a first language as well as for FSL students enrolled in both immersion and core programs.

The short stories vary in topics and themes:

"Le joueur de basket-ball" and "La poignée de main", focus on basket-ball and hockey;
"Un dompteur de lions" and "La chatte d'Espagne", on idiomatic expressions and proverbs drawn from the animal world;

"L'ouvrier modèle", on trades and professions;

"La religieuse qui retourna en Irlande", nationalities and the francophone world;

"Grand-père n'avait peur de rien ni de personne", fears;

"Les cartes postales", post-card writing;

"Nathalie et son bonheur" and "Un très joyeux Noël”, relationship between parents and children;

"À cause d'un peu de fumée", the dangerous effects of drugs and narcotics;

"Les cours en chocolat", on obesity, love and loneliness;

"Une si joyeuse fête", the loss of a dear person; and in

"L'école du rêve", on education.

Carrier is no stranger to the reading audience. His "Hockey sweater", a short film based on his short story "Une abominable feuille d'érable sur glace", produced by the National Film Board of Canada, is considered a classic and the opening lines of the short story in both English and French are found on the five-dollar Canadian bill.

Roch Carrier is the recipient of numerous awards and of honorary degrees granted by both Canadian and American universities. 